ARCHIVO ESPAÑOL DE ARTE, LXXX, 320

OCTUBRE-DICIEMBRE 2007, pp. 379-394

ISSN: 0004-0428

\title{
QUANDO REY PERDEMOS NUNQ[U]A BIEN NOS FALLAMOS... LA MUERTE DEL REY EN LA CASTILLA DEL SIGLO XIII ${ }^{1}$
}

\author{
POR \\ Olga PÉREZ MonZÓN \\ Universidad Autónoma de Madrid
}

El presente artículo trata sobre los ámbitos fúnebres de los reyes castellanos durante el siglo XIII y la particularidad iconográfica de sus monumentos tumulares como reflejo de un ideario político tendente a la sacralización de la monarquía. El encumbramiento de la realeza provocó un abierto conflicto con determinados miembros de la realeza y la familia real y una respuesta política y artística.

Palabras clave: Ceremonia fúnebre. Reyes castellanos. Siglo XIII. Iconografía del monumento fúnebre real.

This article deals with the funeral spaces of the Castilian kings during the $13^{\text {th }}$ century, and the iconography of their tombs as the reflection of a political ideational system tending toward the sanctification of the monarchy. This elevation of royalty provoked an open conflict with certain members of the nobility and the royal family, as well as a political and artistic response.

Key words: Funeral Ceremony. Castilian Kings. $13^{\text {th }}$ century. Royal funerary monument iconography.

La aparición del reloj mecánico en el siglo XIII, contundente sustituto del reloj solar, trajo consigo una regulación más precisa del tiempo. Su medición resultaba fundamental en una Europa de ciudades y mercaderes con detallados horarios comerciales y de negocios ${ }^{2}$. El control regular del tiempo propició en el hombre gótico un doble sentimiento: la conciencia de su paso inexorable y, por consiguiente, de la fugacidad de las cosas terrenas y el deseo de permanencia y fama post mortem como inmortalizó de forma magistral Jorge Manrique (1440?-1479) en los últimos versos de sus famosas Coplas: ... aunque la vida perdió [el maestre don Rodrigo]/ dejónos harto consuelo/ su memoria ${ }^{3}$. En el reino de Castilla del siglo XIII, los sentimientos no debían ser muy diferentes.

\footnotetext{
${ }^{1}$ El presente artículo se enmarca en el proyecto de investigación Las relaciones de conflicto en sus prácticas representativas (la Corona de Castilla en su contexto europeo, siglos XIII-XV). Proyecto HUM2006-05233/HIST del Plan Nacional I+D+I del Ministerio de Educación y Ciencia.

2 Sobre el tema vid. GuRIÉvich, A.: Las categorías de la cultura medieval, Madrid, [1984] 1990, especialmente pp. 176-179.

3 MAnRiQue, J.: Coplas por la muerte de su padre, en Obra completa, dirigida y prologada por A. Cortina, Madrid, 1977, p. 135.
} 


\section{Quando rey perdemos nunq[u]a bien nos fallamos...}

Diversos textos del Mester de Clerecía glosan la biografía de gobernantes y héroes pasados y presentes apreciados por su carácter ejemplar. El relato incluye como paradigma de su actuación su momento mori. Apolonio, rey de Tiro y protagonista del libro homónimo (c. 1240), muere como buen rey en buena fin complida. La situación se repite en el Libro de Alexandre (c. 1200) al relatar el fallecimiento del monarca macedónico convertido por la literatura especular en paradigma del buen gobernante: Fue el rey en tod' esto la palabra perdiendo/ la nariz aguzando, la lengua engordiendo,/ dixo a sus varones: "Ya lo ides veyendo,/ arrenunçió el mundo a Dios vos acomiendo"./ Acostó la cabeça sobre un façeruelo/ non serié omne bivo que non oviesse duelo;/ mandó que lo echassen del lecho en el suelo,/ ca avié ya travado del alma el anzuelo ${ }^{4}$. El façeruelo o almohada, único elemento de su lecho mortuorio, simboliza la humildad con que Alejandro afronta la muerte. Esta actitud, para Lida Maikel, dignifica bajo el aura del cristianismo el comportamiento global del héroe. Ian Michael disiente de esta tesis escatológica y, tras señalar las similitudes del óbito con los de otros monarcas (San Luis de Francia, Fernando I o Fernando III de Castilla), ha apreciado en estos versos la descripción de un modo de morir propio de los reyes del siglo XIII ${ }^{5}$. No es casual hablar de modus morendi privativo de la realeza en un momento de codificación y tipificación del concepto de monarquía.

Tampoco son azarosas las siguientes estrofas del Libro de Alexandre referidas a las consecuencias del deceso real: Señor, con la tu muerte más gentes hay matadas/ que las que en vida tuya mataron tus mesnadas;/ con tu muerte están las tierras angustiadas,/ las mismas que a tu lado vivían alegradas ${ }^{6}$. El paralelismo entre la muerte del rey y la decadencia del reino está presente en otros relatos del Mester de Clerecía como el Libro de Apolonio y, lo que resulta más esclarecedor, en la literatura cronística contemporánea. Hablamos de la Historia Gothica o De Rebus Hispaniae de Rodrigo Jiménez de Rada, del Chronicon Mundi de Lucas de Tuy y de la Crónica Latina de los Reyes de Castilla atribuida a Juan de Osma que, en las acertadas palabras de García de Cortázar, contribuyeron a publicitar y perennizar en la memoria hechos del pasado, del presente vivido y cimentar el dominio del futuro ${ }^{7}$.

Las biografías regias escritas por Rodrigo Jiménez de Rada incluyen su momento final. Las muertes indecorosas, como la del emperador Valente abrasado por las llamas en una choza, constituyen una excepción justificable por su mal ejercicio gubernativo. La mayoría de los monarcas, por el contrario, tienen un digno deceso. La humildad cristiana impera en el fallecimiento de Fernando I (1035-1065) a través del simbólico ademán de quitarse el traje púrpura, mientras que signos extraordinarios predicen los óbitos de Alfonso VI (1072-1109) y Alfonso VII (1126-1157) Ambos gestos -despojo de lo material y profecías anunciadoras- coinciden con el esquema atribuido a otros personajes ejemplares: los santos ${ }^{9}$. La equivalencia semántica, lejos de ser fortuita,

\footnotetext{
${ }^{4}$ Libro de Apolonio, edición, introducción y notas de C. Monedero, Madrid, 1990, p. 292, est. 650 y Libro de Alexandre, edición de J. Cañas, Madrid, 1995, pp. 573-574, ests. 2645 y 2646.

5 LidA MAikel, R.: La idea de la fama en la Edad Media Castellana, Mexico, 1952, pp. 196-197 y Michael, I.: "Interpretation of the Libre de Alexandre. The Author's Attidude towards his hero's death", en Bulletin of Hispanic Studies, XXXVII (1960), 205-214.

${ }^{6}$ Libro de Alexandre, p. 576, ests. 2657 y 2658.

7 "Cultura en el reinado de Alfonso VIII de Castilla: signos de un cambio de mentalidades y sensibilidades", en II Curso de Cultura Medieval. Alfonso VIII y su época, Madrid, 1992, 167-194. Los tres autores -Rada, Tuy y Osma- coinciden al considerar el carácter ejemplar de los actos regios y, de forma específica, el momento de su muerte.

8 JiMÉNEZ DE RADA, R.: Historia de los Hechos de España, introducción, traducción, notas e índices de J. Fernández Valverde, Madrid, 1989, p. 89, Libro II, Cap. II; p. 237, Libro VI, Cap. XIII; p. 263, Libro VI, Cap. XXXIIII y p. 279, Libro VII, Cap. XI.

${ }^{9}$ Establece el citado paralelismo GuiAnce, A. al tratar sobre la muerte del rey, (Los discursos sobre la muerte en la Castilla medieval (siglos VII-XV), Junta de Castilla y León, 1998, p. 290).
} 
hemos de valorarla en el contexto del siglo XIII tendente a la sacralización de la institución monárquica.

Todas las muertes causan dolor, lamentaciones y un inconsolable desconsuelo entre sus súbditos como ejemplifica el obituario dedicado a Alfonso VIII (1158-1214):... comenzó a enfermar de gravedad... acabó por morir y con él enterró a la gloria de Castilla,... Y se produjo el desconsuelo de todos y la orfandad de los nobles, además de la de todas las gentes... ${ }^{10}$. En similares términos de aflicción, orfandad y destino luctuoso del reino, glosaron la muerte del fundador del monasterio de las Huelgas Juan de Osma o Lucas de Tuy. Alfonso X (1252-1284) utilizó una similar plática en la Estoria de España al relatar el fallecimiento de su padre, el rey Fernando III (1217-1252): ¿Et quien uio tanta duenna de alta guisa et tanta donzella andar descabennadas et rascadas, ronpiendo las fazes et tornandolas en sangre et en la carne biua? ¿Quien vio tanto infante, tanto rico omne, tanto infançon, tanto cauallero, tanto omne de prestar andando baladrando, dando bozes, mesando sus cabellos et ronpiendo las fruentes et faziendo en sy fuertes cruezas? ${ }^{11}$. Los mismos gestos reaparecen en la General Estoria en el fallecimiento de Alejandro Magno: E era muy gran el lloro e el llanto en aquel logar, tanto que semeiaua trueno... Començaron entonces todos los Macedonios a llorar e a dezir a muy grandes bozes: "Meior fuera a nos de morir nos todos que uer la tu muerte ${ }^{12}$.

La desmesura de sentimientos, común a todos los relatos, se justifica en la identidad rey-reino convertida en un axioma común por la teoría política del momento, tal como sentencia un verso del Libro de Apolonio: quando rey perdemos, nunq[u]a bien nos fallamos ${ }^{13}$.

\section{2. Ámbitos fúnebres regios}

La pena por el óbito se exterioriza en las ceremonias del adios y el respeto al monarca difunto en la honra debida a su lugar de sepultura: Otrossí dezimos quel lugar o rrey fuere soterrado, que deve ser onrrado e guardado en todas cosas assí como las cosas del rey bivas que á por todo el rregno, e esto por onrra del rrey que y yaze ${ }^{14}$. De este modo, el Speculo de Alfonso $\mathrm{X}$ exige honor y respeto a los ámbitos fúnebres regios. El plural corresponde plenamente a la realidad castellana del siglo XIII ya que, pese a la insistencia en el concepto de linaje y por tanto perduración de la línea dinástica, los panteones regios no tuvieron una larga pervivencia. Razones políticas, la constante variación de las fronteras y el proceso de expansión-consolidación del reino justifican estos cambios que, en último término, buscan ligar el nombre de un rey a un templo determinado. El Poema de Fernán González lo expresa claramente en la disertación del conde sobre su sepultura en la ermita de Arlanza -demás, quando muriere,aquí me soterrar/ que mejore por mí siempre este lugar ${ }^{15}$ _. Es interesante enfatizar la dirección de esta coordenada: la fama del santuario deriva del cuerpo ilustre que allí reposa y no a la inversa. Los

\footnotetext{
10 JiMÉNEZ DE RADA: Historia de los Hechos de España, p. 329, Libro VIII, Cap. XV.

11 Nuevamente los textos alfonsíes son contradictorios en su contenido al reclamar circunspección en las manifestaciones de duelo y relatar el dolor inconmensurable de los castellanos en el óbito de Fernando III en la Crónica General de España (Primera Crónica General de España, II, pág. 773, cap. 1134).

12 Alfonso X: General Estoria, en Prosa histórica, edición B. Brancaforte, Madrid, 1984, pág. 260.

13 Libro de Apolonio, p. 110, v. 47d. Sobre el tema resultan de obligada lectura los trabajos de NIETo SoRIA, J.M., especialmente: "La transpersonalización del poder regio", en Anuario de Estudios Medievales, Madrid, 17 (1987), 559-570.

${ }^{14}$ Leyes de Alfonso X. I. Especulo, edición y análisis crítico G. Martínez Díez, colaboración J.M. Ruiz Asencio, Ávila, 1985, p. 179, Libro II, Título XVI, Ley II. El monarca castellano reincide sobre el mismo tema en la Primera Partida, Título XIII, Leyes XI y XIIII.

15 El conde ennoblece, de este modo, la pobre ermita donde mora el visionario monje Pelayo (Poema de Fernán González, p. 95, est. 245 -249).
} 
argumentos señalados determinaron que en la Castilla del siglo XIII hubiera tres lugares de inhumación regia: el monasterio de Santa María la Real de las Huelgas (Burgos) y las catedrales de Sevilla y Toledo.

La posición emblemática ocupada por Burgos en el naciente reino castellano incidió favorablemente en la decisión de Alfonso VIII de fijar en esta ciudad un nuevo panteón dinástico. El templo elegido fue su fundación de Santa María la Real de las Huelgas convertida en casa madre de los monasterios cister femeninos en Castilla y León, residencia palatina y escenario de actos relevantes de la familia real ${ }^{16}$. Los cuerpos de los reyes permanecieron en la capilla de la Asunción hasta su traslado definitivo al coro de la actual iglesia en una fecha anterior a 1279, año de la consagración de los altares y cementerios del nuevo templo ${ }^{17}$ [figura $\mathrm{n}^{\mathrm{o}} 1$ ].

Es fácil imaginar los inconvenientes litúrgicos derivados el emplazamiento privilegiado del túmulo real. También los beneficios. Las plegarias de las toquinegradas no podían sustraerse de la memoria de los fundadores que de facto presidían este espacio religioso. Visualizamos la excepcionalidad que las Partidas atribuyen a los enterramientos ilustres y una meditada jerarquización del espacio que motivó el desplazamiento a lugares secundarios de las tumbas del infante de la Cerda, frustrado heredero de Alfonso X; doña Berenguela, hija de los fundadores y madre de Fernando III; y doña Blanca, nieta de Alfonso X, abadesa de las Huelgas y promotora de la conclusión de las obras del cenobio. La rígida prelación del panteón provocó situaciones tensas como la mantenida en 1319 entre los deudos del infante don Pedro y la abadesa de las Huelgas sobre el enterramiento del hermano de Fernando IV en el coro ${ }^{18}$.

La decisión de Alfonso VIII tampoco tuvo fortuna ya que el cadáver de su sucesor Fernando III, promotor de importantes obras en las Huelgas, fue enterrado en una capilla situada en la iglesia-mezquita de Sevilla con el fin de conmemorar la conquista en 1248 de la antigua capital almorávide y almohade de $\mathrm{Al}$-Andalus. El sepelio posterior de Alfonso X enfatizó el carácter institucional de este ámbito: ... Et si los nuestros testamentos tovieren por bien de enterrar el nuestro cuerpo en Seuilla, mandamos que lo fagan allí do entendieren que será mejor, pero desta guisa; que la sepultura non sea mucho alta, e si quisieren que sea allí do el rey don Ferrando e la reyna donna Beatriz yacen, que fagan en tal manera que la nuestra cabeça tengamos a los sus pies damos a dos, e que sea la sepultura llana, de guisa que quando el capellán viniere dezir oraçión sobre ellos e sobre nos, que los pies tenga sobre la nuestra sepultura. La humildad cristiana que transmite el testamento del rey, como hemos visto, corresponde a un discurso arquetípico del relato cronístico poco coincidente con la realidad ya que magnificencia y esplendor son dos de los epítetos atribuidos a este ámbito regio que, en palabras de Laguna Paúl, fue la más certera expresión de las aspiraciones políticas de la monarquía castellano-leonesa que en plena fase de autoafirmación eligió como prototipo a Fernando III'19.

\footnotetext{
16 Para la cronología del cenobio, la funcionalidad primitiva de la capilla de la Asunción y los usos del monasterio vid. Muñoz PÁrRaGa, $M^{\text {a }}$ del C.: Monasterios de monjas cistercienses, Madrid, 1992, p. 28. De reciente aparición los textos de YARZA, J.: "Monasterio y palacio del rey" y M ${ }^{\mathrm{a}} \mathrm{J}$. Gómez Barcena: "El Panteón Real de las Huelgas de Burgos", en Vestiduras ricas El monasterio de las Huelgas y su época 1170-1340, Madrid, 2005, respectivamente, pp. 15-34 y 51-72. Realizado este trabajo, se ha publicado por G. PALOMO y J.C. Ruiz SouZA, "Nuevas hipótesis sobre las Huelgas de Burgos. Escenografía funeraria de Alfonso X para un proyecto inacabado de Alfonso VIII y Leonor Plantagenet", Goya, 316-317 (2007), 21-45.

17 LizoAín GarRido, J.M: Documentación del monasterio de las Huelgas de Burgos 1263-1283, Burgos, 1987, pp. 112$113, \mathrm{n}^{\circ} 596$

18 La cita es recogida por BANGO TORvISO, I.G. en un trabajo básico sobre el arte funerario medieval castellano: "El espacio para enterramientos privilegiados en la arquitectura medieval española", en Anuario del Departamento de Historia y Teoría del Arte, Madrid, IV (1992), especialmente pp. 117-118.

19 "La aljama cristianizada. Memoria de la catedral de Santa María de Sevilla", en Metropolis Totius Hispaniae 750 aniversario de la incorporación de Sevilla a la corona castellana, Sevilla, 1998, 41-71. En este tema, seguimos los planteamientos de la citada autora.
} 
El culto que, desde un primer momento, recibió la tumba del rey santo obligó a reorganizar el espacio de la antigua aljama y a su separación en dos ámbitos cultuales, la capilla de los Reyes y la capilla mayor, presididos respectivamente por las tallas de la Virgen de los Reyes y la Virgen de la Sede ${ }^{20}$. Dos fechas nos ayudan a situar cronológicamente este espacio regio: 1252 y 1279. La primera data coincide con la muerte de Fernando III y su entierro bajo el pavimento de la catedral por no tener túmulo funerario. La segunda con el traslado de los restos mortales de Beatriz de Suabia desde el cenobio burgalés de las Huelgas, tras la conclusión del nuevo recinto fúnebre ${ }^{21}$.

Lo particular de la topografía hispalense fue cómo se concretó la división de la catedral aljama al corresponder al ámbito regio, en el lado oriental de la nave del haram, unas dimensiones muy notables. Si sorprendente era su equiparación de facto con el templo propiamente dicho, más impactante resultaba su delimitación por una reja de hierro que si bien acotaba su espacio no ocultaba a la feligresía su interior ${ }^{22}$. Su iluminación permanente por velas y la sobreelevación de su pavimento mediante unas bóvedas de ladrillo contribuían definitivamente a la publicitación del mensaje político-religioso condensado en la talla de la Virgen de los Reyes, los simulacros regios de Fernando III, Alfonso X y Beatriz de Suabia y los sarcófagos ${ }^{23}$.

Estos ámbitos fueron reverenciados y honrados por sus súbditos. Como nuevos santos, se acudía a ellos en busca de acciones taumatúrgicas. Así lo expresa Ángela Sandoval, abadesa de las Huelgas en 1624: ... tiene noticia del Sancto Rey Don Alonso el Octavo... y que está su cuerpo enterrado en este monasterio en honorífico sepulcro el qual vee de ordinario por estar en el choro deste combento y ha venerado y venera como sepulcro de cuerpo sancto ... y que en el dicho tiempo y siempre ha oído decir a las relixiosas más antiguas de él y a otras muchas personas viexas ancianas de cuios nombres no se acuerda que los peregrinos que iban camino de Santiago visitaban el dicho Sepulcro y hacían oración delante de él como de cuerpo sancto asta que el sancto concilio puso clausura en los combentos de las Religiosas y sabe este testigo que oy dura la memoria de los lugares por donde iban los dichos peregrinos a visitar el dicho sepulcro y que se llama la carrera de Santiago ${ }^{24}$. El citado extracto pertenece a un curioso documento sobre la canonización de Alfonso VIII promovida por su sucesor Felipe IV. El texto refiere sus presuntos milagros, las apariciones celestiales que recibió en vida y, como hemos visto, el culto dispensado a su sarcófago. Consideramos plausible retrotraer el homenaje de los peregrinos jacobeos a época medieval. Esta circunstancia contribuiría notablemente a la publicitación del espacio fúnebre regio que recibía asiduamente los cantos litúrgicos de las Señoras

${ }^{20}$ Esta práctica devocional queda avalada por las indulgencias concedidas por Inocencio IV en 1252 y Alejandro IV en 1254 y 1255 a los fieles que rezasen ante la tumba de Fernando III. Cit. SANZ, M ${ }^{\mathrm{a}}$ J.: Ajuares funerarios de Fernando III, Beatriz de Suabia y Alfonso X”, en Sevilla 1248, coord. M. González Jiménez, Sevilla, 2000, p. 419.

${ }^{21}$ Precisa estos datos MartíneZ de AguirRe, J.: "La primera escultura funeraria gótica en Sevilla: la capilla Real y el sepulcro de Guzmán el Bueno (1248-1320)", en Archivo Español de Arte, Madrid, 270 (1995), 111-129. Sobre las dimensiones de este espacio regio Ruiz Souza, J.C.: "Las capillas reales catedralicias bajomedievales de Sevilla, Toledo y Córdoba", en Jornadas técnicas de conservadores de las catedrales. Las catedrales en España, Alcalá de Henares, 1998. Citamos también el clásico trabajo de Comez Ramos, C.: Empresas artísticas de Alfonso X el Sabio, Sevilla, 1979.

22 Espinosa de los Monteros, en el siglo XVII, utilizando una documentación hoy desaparecida ya evocó la particular fisonomía de este ámbito fúnebre: la parte de Oriente hazia la Torre, hizo capilla Real, dexando franco passo al rededor della, para que se penetrase la vista por todas partes, cercandola de rejas de hierro [Teatro de la Santa Iglesia Catedral de Sevilla, 1884 (1635), pp. 33-34].

23 Según Laguna PaÚL, esta plataforma abovedada debía ser semejante a la mandada construir por Alfonso X entre 1250 y 1260 en la capilla Real de la catedral de Córdoba. Su utilidad fue variada al permitir disponer un panteón inferior para otros miembros de la realeza y ubicar en su parte posterior la sacristía y otras dependencias secundarias ("La Aljama cristianizada", p. 60).

24 AHN, Códices, sign. 771 B, Compendio de las informaciones, compulsas de Historias y ottras en latin, castellano e italiano practicada acerca de la santidad, vida, fama y milagros del Bien aventurado Sor Rey don Alonso Octtavo el Bueno y Noble de Castilla para su beatificación y de canonizazión. Año 1624, $3^{\mathrm{er}}$ cuaderno, fol. 11. 
de las Huelgas y, en puntuales ceremonias de carácter cortesano, la visita y contemplación de la elite del reino. En el recinto, se celebraron las armaduras como caballeros de Fernando III, Alfonso X o Juan I y, como recordaba el viajero Lalaing al describir el viaje de Felipe el Hermoso en 1505 a Castilla era costumbre echar pie a tierra los príncipes de Castilla a su entra$d a$, cuando entran en la ciudad de Burgos en una abadía de monjas de clausura, llamadas las doncellas ${ }^{25}$.

La capilla hispalense fue escenario de notables ceremonias político-cortesanas. Llamativas fueron las vinculadas al aniversario de Fernando III. El 29 de mayo los atributos regios por excelencia -espada y corona- se depositaban en dos almohadones de terciopelo dispuestos sobre el túmulo del rey. La remembranza de don Fernando culminaba al día siguiente con la ofrenda de los pendones descrita en la Crónica de Alfonso X: ... Venían muy grandes gentes de muchas partes de Andaluzia a esta onra et trayan todos los pendones et las sennas de cada uno de sus lugares. Et con cada pendón trayan muchos çirios de çera et ponían todos los pendones que trayan dentro en la Yglesia Mayor e acendían los cirios de muy gran mannana e ardían todo el dia, ca eran los çirios muy grandes... E este aniuersario fizo este rey don Alfonso cada anno syenpre que quanto ovo los reynos en su poder. Et avía por costumbre que este día del enavesario (sic) nin otro ante que non abrían tiendas ningunas nin los menestrales non fazían ninguna $\cos a^{26}$. Imaginamos impactante el espectáculo con el tremolar de las insignias y la iluminación de cirios. Miniaturas góticas algo más tardías confirman la presencia de ambos elementos en los funerales corpore in sepulcro donde los cirios, además de rodear el monumento tumular, solían cubrir las estructuras que a modo de baldaquino se colocaban sobre el féretro ${ }^{27}$. Las velas aportan el simbolismo cristiano; mas los pendones son metáforas de ciudades, reinos o gobernantes y, por tanto, representaban el vasallaje y respeto al monarca fallecido. La ceremonia sevillana perpetuaba en el recuerdo las exequias de Fernando III y, por tanto, la buena memoria del rey.

No menos significativa resultaba la celebración en la mezquita-aljama de la fiesta de San Clemente, conmemorativa de la fecha de la conquista de la ciudad, con la procesión solemne de dos útiles bélicos de arraigado simbolismo: el pendón y la espada de San Fernando (tesoro de la Capilla Real). La tradición otorgaba al tejido militar la publicitación del triunfo cristiano al ondear victorioso sobre el yamur de la Giralda ${ }^{28}$. La espada es el útil por excelencia del miles Christi y del guerrero victorioso. La tradición asimismo exigía que, continuando el gesto primero de Alfonso $\mathrm{X}$, los sucesores de la corona fuesen los portadores del arma. Felipe II asignó este oficio al Asistente de la ciudad, mas desde la canonización del monarca sabio en 1671, los capellanes de la Capilla Real reclamaron este privilegio para un religioso invocando su condición de reliquia ${ }^{29}$. La petición se apoya en una larga tradición que otorga al útil bélico un carácter apotropaico por tener la virtud de curar a los que le besaran ${ }^{30}$; durante el resto del año, el simulacro de Fernando III blandía la espada con su mano diestra ${ }^{31}$.

25 Lalaing, A. de: Primer viaje de Felipe el Hermoso a España en 1501, recopilado por García Mercadal, Viajes de Extranjeros por España y Portugal, Junta de Castilla y León, t. I, 1999, p. 415.

26 Crónica de Alfonso X. Según el Ms. II/1277 de la Biblioteca del Palacio Real (Madrid), edición M. GonZÁLEZ JiMÉNEZ, Murcia, 1998, cap. IX, p. 27.

27 Como ejemplo citamos «La capilla ardiente» de las Trés belles heures de Notre Dame (siglo XV, fol. 104).

28 Martínez Nuñez, J.C.: "Pendón de San Fernando", en Metropolis Totivs Hispaniae, pp. 240-241.

29 Martínez NuñEZ, J.C.:"Espada de San Fernando", en Metropolis Totivs Hispaniae, p. 234.

${ }^{30}$ Sobre el tema vid. ChamberLin, C.L.: " 'Unless the pen writes as it should': The proto-cult of Saint Fernando III in Seville in the thirteenth and fourteeth centuries", en Sevilla 1248, 389-417.

31 De problemática cronología, parece que la espada actual es el resultado de diferentes intervenciones. No obstante, hay cierta unicidad entre los estudiosos de considerar el arriaz de época fernandina (SANZ, M ${ }^{\mathrm{a}} \mathrm{J} .:$ "Ajuares funerarios", pp. 435-436 y "Espada de San Fernando", en Maravillas de la España Medieval Tesoro sagrado y monarquía, León, 2000, pp. 102-103). 


\section{Sepulcros regios}

Los relatos cronísticos, como hemos visto, con un meditado sentido político resaltan la humildad que impera en los decesos reales. Por el contrario, la información es escueta al referirse al tratamiento del cadáver, las formas de enterramiento o la obra escultórica que lo cobija.

\subsection{Sobre el cuerpo real}

Cuando Antonio Ponz, describe el sepulcro del infante don Felipe en Villálcazar de Sirga menciona que el obispo de Palencia hizo poner llave a la urna del infante no ha muchos años porque antes era fácil destaparla, y con todo eso se conservaba entero el cadáver, con su pellejo ${ }^{32}$. El relato dieciochesco, además de señalar el deterioro del cenotafio, constata la práctica mantenida durante la Edad Media de embalsamar los cuerpos ilustres. El hemistiquio como costumbre era, repetido en el Libro de Apolonio y el Poema de Fernán González sobre el tratamiento de los cadáveres de Luciana, mujer de Apolonio ${ }^{33}$, y el conde de Tolosa, digno rival del conde castellano, corrobora la vigencia de este rito mortuorio que concluía en el aderezo del cadáver con ricas vestimentas ${ }^{34}$. La muerte no era igualatoria y el traje expresaba la condición social del finado.

Ricas vestiduras, -indican las Partidas-nin otros guarnimientos preciados, assi como oro o plata, no deve meter a los muertos, si non a personas ciertas, assi como a Rey, o a Reyna, o a alguno de sus hijos ${ }^{35}$. Testimonios literarios diversos refrendan el contenido del texto alfonsí. El conde Fernán González amortaja a su rival muerto con un traje de xamete -tela preciosa ${ }^{36}$ - y ropa rica es el sudario de la mujer de Apolonio como corresponde a su condición de reyna honrrada y non pobre romero ${ }^{37}$. Las citas literarias coinciden plenamente con los restos artísticos conservados.

Los cuerpos de Alfonso VIII y Leonor de Plantagenet fueron momificados y revestidos con sendos trajes de aparato ${ }^{38}$. El citado documento de 1624 detalla el reparto de la mortaja fúnebre del rey entre las monjas y sus parientes por considerarlas de carácter profiláctico. La superiora Magdalena Henríquez menciona la sanación de una monja al ponerle sobre su cara un retazo del aforro de la tumba sancta y la priora Ángela Sandoval cómo al visitar en 1588 el obispo Sebastián el templo se descubrió la tumba estando rostro y manos sin faltar cosa alguna y las vestiduras sanas y buenas... Las vestiduras se han repartido entre muchas y diversas personas, que se tienen por reliquias ${ }^{39}$.

\footnotetext{
32 PonZ: Viaje de España 3, Madrid, [1786] 1988, p. 483.

33 La muerte de la mujer de Apolonio motiva la descripción del rito mortuorio seguido: Balsamaron el cuerpo como costumbre era,/ fiziéronle armario de liuiana madera,/ engludaron las tablas con englut e con çera,/ bolbiéronlo en ropa rica de gran manera./ Con el cuerpo abueltas, el su buen/ conpanyero/metió XL pieças de buen oro en el tablero;/ escriuyó en hun plomo con hun grafio d'azero/ letras, qui la fallase por onde fuese certero./ Quando el ministerio todo acabado,/ el atahút bien preso, el cuerpo bien çerrado,/ vertieron muchas lágrimas mucho varón rascado,/ fue ha pesar de todos en las ondas echado (Libro de Apolonio, pp. 181-182, ests. 281-283).

34 Poema de Fernán González, p. 116, ests. 376-381.Trata de forma detallada este aspecto EsPañol BERTRÁN, F.: «Los indumentos del cuerpo a la espera del Juicio Final», en Ricas vestiduras, 73-88.

35 Alfonso X: Primera Partida, Título XIII, Ley XIII.

36 Poema de Fernán González, p. 116, ests. 376-381.

37 Libro de Apolonio, p. 181, est. 281. Alejandro responde de esa manera al marinero que, con premura, quería echar el cuerpo de Luciana al mar (Libro de Apolonio, p. 179, est. 275). La contraposición se explica por el mal tratamiento dado en los viajes a los peregrinos pobres.

38 Vid. Gómez Moreno, M.: El Panteón Real de las Huelgas de Burgos, Madrid, 1946, pp. 25-28.

39 AHN, Compendio... de canonización, Sign. 771 B, $3^{\text {er }}$ cuaderno, fols. 22 y 14.
} 
Similares circunstancias se repitieron tras la apertura del atáud de Fernando III en 1668 en el proceso de canonización del monarca. Uno de los testigos seleccionados para corroborar el buen estado de conservación del cuerpo, Cristóbal Bañez de Salcedo, menciona textualmente los buenos pedazos que le tocaron del vestido real codiciado como una reputada reliquia ${ }^{40}$. Los fragmentos conservados constatan la suntuosidad de la vestimenta regia jaquelada de las armas de Castilla y León. El ajuar funerario contenía como regalia principal la espada y dos útiles ecuestres ligados a su condición de miles Christi, el tellix o paño para la silla del caballo de color carmesí y los acicates (c. 1217-1230) ornados con diez castillos grabados con punta de plata. El valor apotropaico de estas piezas del arnés determinó que durante casi dos siglos se guardaran en el Relicario de la Real Capilla ${ }^{41}$. Fernando III dispuso además su enterramiento con la talla mariana de la Virgen de las Batallas (primera mitad del siglo XIII-c. 1275) que, según las Crónicas, acompañó al monarca sujeta a su arzón durante la conquista de la ciudad ${ }^{42}$. Nuevamente, citamos un objeto de valor taumatúrgico empleado por las generaciones venideras; en este caso, fue su hijo Alfonso X quien sacó la imagen durante el asedio y conquista de Murcia ${ }^{43}$.

Suntuosa, asimismo, era la mortaja de Alfonso X con dalmatica o pellote, bolso, espuelas y guantes con decoración heráldica, gorro con perlas, coral y vidrio azul con dobles cruces de lámina de plata dorada y unas almohadas con leones, castillos y águilas. Completaban el ajuar como significativas regalias la espada, la corona y el cetro imperial.

El infante don Felipe, hermano de Alfonso X, fue enterrado, asimismo, con ricas vestiduras. La magnificencia de su ajuar y el ornato heráldico de su capiello y capa sintonizan con las relativas a las mortajas regias, a la vez que guardan unos estrechos paralelismos con la vestimenta de Alfonso X en las viñetas de las Cantigas ${ }^{44}$. Nuevamente encontramos en los gestos del hijo de Fernando III unos buscados paralelismos con el quehacer regio ${ }^{45}$.

\subsection{Particularismos en los monumentos tumulares regios}

La fama, entendida como buena memoria, del monarca difunto constituye un elemento fundamental en la Castilla del siglo XIII: Aviendo el Rey niño -señalan las Partidas - ... de fazer estas cosas, por el rey finado... E otrosí en fazer guardar su fama, assí que los que en su vida, non dixeron mal del, non lo digan en su muerte ${ }^{46}$. Lo remarcable del texto alfonsí no es sólo la mención

\footnotetext{
40 Cit. Herrero, C.: "Fragmento del manto de Fernando III", en Metropolis Totivs Hispaniae, p. 238. Los restos de la indumentaria real están en la Armería Real de Madrid y la catedral de Sevilla.

${ }^{41}$ Este sable, probablemente de época fernandina, en la actualidad se custodia en el interior del sarcófago ( SANZ, M J.: "Ajuares funerarios", pp. 438-439). Sobre las espuelas vid. SOLER DEL CAMPO, A.: "Acicates (espuelas) del rey Fernando III", en Metropolis Totivs Hispaniae, p. 236.

42 Ma Luisa Melero analiza la advocación de la Virgen de las Batallas como expresión de la protección emanada de la Virgen en los actos bélicos. La citada tradición hispalense, justamente, identifica a la Madre de Cristo como la acompañante de Fernando III en su entrada triunfal en la ciudad ("La Virgen y el rey", en Maravillas de la España medieval, pp. 420-421).

43 Al trasladar el cuerpo de Fernando III a una nueva urna en 1729, la talla mariana pasó a una de las dependencias de la Capi1la Real de la catedral de Sevilla (HeRnÁNDEZ NuÑEZ, J.C.: "Virgen de las Batallas", en Metropolis Totivs Hispaniae, pp. 242-243).

44 Diferentes avatares han determinado que tan destacada mortaja hoy figure repartida entre el Museo Arqueológico Nacional, el Instituto Valencia de don Juan, la Hispanic Society y la Cooper Union Museum de Nueva York. Entre otros, vid., FRANCo Mata, A.: "Bonete del infante don Felipe", en Ricas vestiduras, pp. 177-178.

45 Pérez Monzón, O.: "Las exequias fúnebres como tema artístico. El sepulcro del infante don Felipe de Villalcázar de Sirga", en prensa.

46 El texto continúa explicitando su aseveración: Ca pues que non tiene daño al finado nin pro al que lo dize, muestrasse por atrevido el dezidor e tornasse en deshonrra del Rey niño por que non lo deue soffrir en ninguna manera. E segund justicia, e derecho, como querría que fiziessen a él en su muerte, assí lo deue el fazer por la ánima del finado ques que finca en su lugar, e ereda sus bienes. Ca derecho es, que como gana la honrra, e el pro de aquél a quien ereda, que así tome la carga e el embargo de lo que avía de fazer (ALFONso X: II Partida, Título XV, Ley IIII).
} 
de la fama entre las obligaciones debidas al monarca fallecido sino su equiparación a otras premisas de tinte escatológico ${ }^{47}$. Lo último determina el recitado de oraciones y la entrega de limosnas, lo primero la remembranza de los principales actos del rey.

El mismo discurso aparece en los textos de Clerecía donde se insiste en la bondad de contar las acciones memorables de gobernantes y reyes. Los habitantes de Tarso y Mitelene individualizan las estatuas de Apolonio, ofrecidas como presentes, con inscripciones curriculares para que fasta la fin del mundo e el siglo pasado el don de Apolonio non fuese olvid[ad] ${ }^{48}$. Del mismo modo, la tienda de Alejandro Magno se adornaba con las pinturas de Apeles que bien contar [supo] las gestas del buen rey y el conde Fernán González estimulaba a los castellanos en los momentos previos al enfrentamiento contra Almanzor en Hacinas con la promesa de una batalla inmortal que, quanto el mundo perdure, sienpre será contado ${ }^{49}$. Juzgamos interesante resaltar esta idea por sus conexiones con la iconografía desarrollada en los monumentos tumulares regios.

\subsubsection{Serán los buenos fechos fasta la fin contados... Los relieves historiados de los sepulcros de Alfonso VIII y Leonor de Plantagenet}

El doble cenotafio de Alfonso VIII y Leonor de Plantagenet (segunda mitad del siglo XIII) adorna sus laterales, testeros y tapas con motivos heráldicos [figura $\mathrm{n}^{\circ} 2$ ]. Este ornato, habitual en los cenotafios medievales desde el siglo XIII, es la traslación plástica de la práctica consuetudinaria de colocar señales y armerías sobre los sarcófagos. Tal costumbre tenía un origen ritual, tapar o envolver las tumbas con armas militares, y un motivo simbólico, el valor del escudo como sustituto del finado. Según expresan las Partidas, el monarca, y por extensión el noble, puede significarse del mismo modo a través de su persona, su imagen, su palabra escrita convenientemente rubricada por el sello o sus armas ${ }^{50}$. De forma significativa, los castillos de Alfonso VIII tienen el formato de señal al no inscribir el mueble en una cartela. La precisión no resulta arbitraria ya que la señal es una referencia de carácter territorial que, además, Alfonso VIII empleó en la constitución de su armería al convertirlo en un distintivo genealógico y familiar ${ }^{51}$. Con la elección de las señales de los castillos en el túmulo y la significación del monarca por el símbolo del país o territorio, se enfatiza en la identidad rey-reino auspiciada por la teoría política del momento. Los tres leopardos, alusivos al linaje Plantagenet, se inscriben en escudos de armas y la peculiaridad de ir coronados corresponde a la intención de identificar con nitidez la armería real extranjera privativa de doña Leonor.

En los triángulos resultantes de las albardillas funerarias, se cincelaron cuatro relieves figurativos. Los de doña Leonor son de tinte escatológico -una crucifixión y una escena de psicostasis

\footnotetext{
47 Assí como e dar limosnas por su ánima e fazer dezir missas, -continúa el texto alfonsí- e otras oraciones, rogando a Dios que le aya merced. E otrosí en pagar sus debdas, e en cumplir sus mandas, e en fazer algo a los suyos, que lo ovieren menester, que non finquen desamparados. El castigo afectará a los que no cumplan estos mandatos: E faziéndolo assí, estar le ha muy bien, que quantos lo oyeren lo preciarán más por ende, e le ternan por más leal, e de más aurá siempre buena fiuzia, que los que heredar lo suyo ansí farán por el quando finare... Onde el Rey que esto non fiziesse, auerlo yan por enatio e por desmesurado, e aun pro torticero, que son cosas que le estarían mal en este mundo; e por que le daría Dios pena en el otro, como aquél que deuiera guardar egualdad a todos, en non la guardó en sí mismo (Alfonso X, II Partida, Título XV, Ley IIII).

48 Libro de Apolonio, p. 125, ests. 96 y 97.

49 Libro de Apolonio, p. 125, ests. 96 y 97 y Poema de Fernán González, p. 144, est. 553. Similares contiendas, dignas de ser recordadas, protagonizaron gobernantes del pasado como Alejandro -non cuentan d'Alexandre las noches nin los días/cuentan sus buenos fechos e sus cavallerías- o el bíblico rey David -cuentan del rey Davit que mato a Golias- (Poema de Fernán González, pp. 112-113, ests. 354-356).

50 ALFONSO X: Segunda Partida, Título XIII, Ley XVIII.

51 Vid. Pérez Monzón, O.: "Iconografía y poder real en Castilla: las imágenes de Alfonso VIII", Anuario del Departamento de Historia y Teoría del Arte, Madrid, XIV (2002), pp. 28-29.
} 


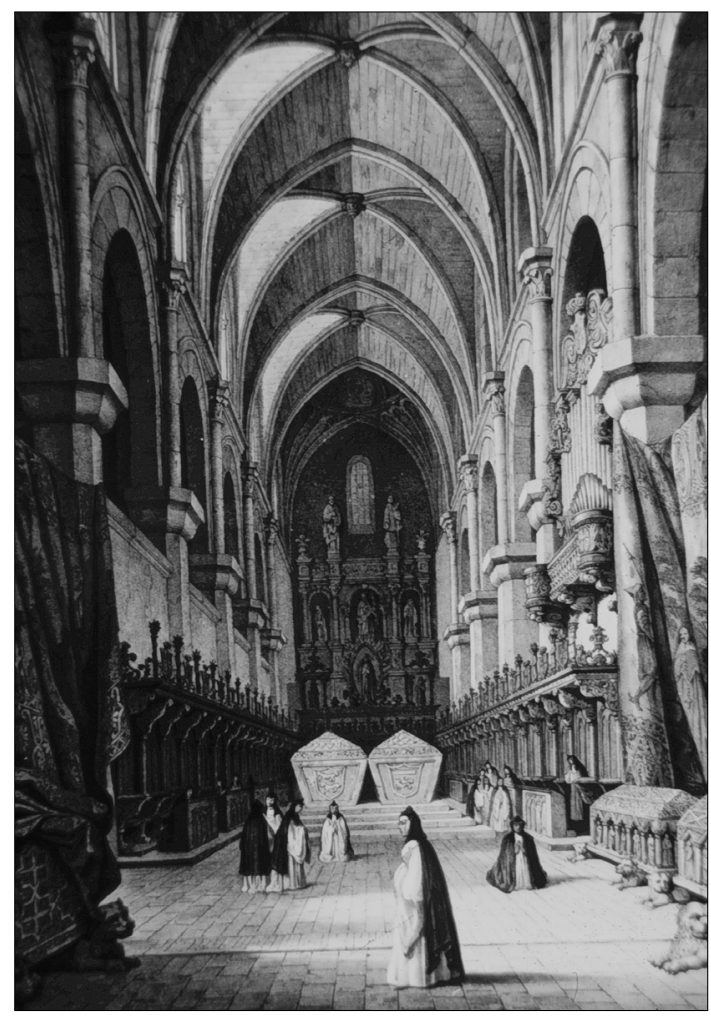

Fig. 1. Interior del coro de las Huelgas de Burgos (España artística y monumental, 1844).

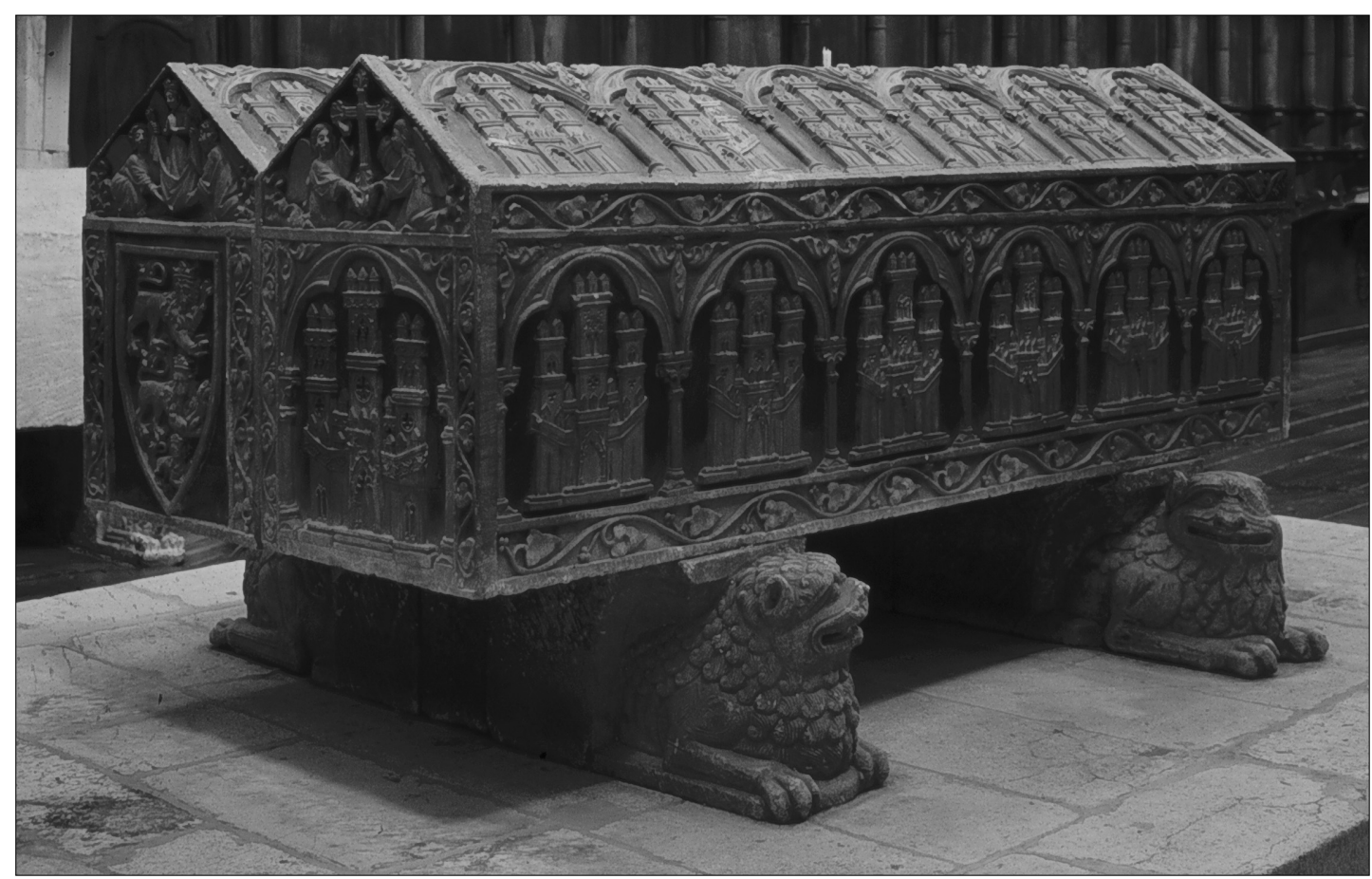

Fig. 2. Sarcófagos de Alfonso VIII y Leonor de Plantagenet (Monasterio Santa María la Real de las Huelgas). 
o elevatio animae con la representación de su alma coronada-; mientras que los del rey tienen un matiz político -la fundación del monasterio de las Huelgas y una cruz anicónica, alusiva a la batalla de las Navas de Tolosa [figura $\mathrm{n}^{\mathrm{o}} 3$ ] -. Detenemos nuestra atención en estos últimos.

La fundación monástica se efigia en la entrega del documento de donación por Alfonso VIII a doña Misol como primera abadesa de las Huelgas y sus acompañantes [figura $\mathrm{n}^{\circ} 4$ ]. Mas en el relieve tumular, el sentido piadoso del gesto, se transforma en una escena de homenaje al monarca que, con corona, descansa en un trono de cabezas de león -trono de Salomón o trono de sabiduría-. Apreciemos la situación central del monarca, su perspectiva jerárquica y la posición genuflexa, en actitud orante, de las Señoras de las Huelgas. La secuencia narrativa reproduce el esquema de una característica escena de homenaje, particularmente de una Epifanía, donde la Virgen-trono del Niño ha sido sustituida por el rey entronizado y los magos por las toquinegradas ${ }^{52}$. Destacable, asimismo, es que el objeto donado no se represente a través de una maqueta arquetípica del edificio monástico, conforme a un modelo iconográfico ya establecido, sino a través de un rollo con un sello colgante que, según explicitan las Partidas, acredita la autenticidad de las palabras. El hecho es relacionable con el protagonismo adquirido desde el siglo XII por la literalidad frente a la oralidad y la clara intención de cifrar de forma textual los hechos dignos de ser recordados ${ }^{53}$.

El cenotafio de Alfonso VIII combina la secuencia de la entrega a Doña Misol con una cruz de brazos desiguales alusiva a la festividad litúrgica de la Exaltación de la Cruz y a la cruz de las Navas de Tolosa, principal acontecimiento bélico protagonizado por Alfonso VIII y auténtico hito en la cruzada contra el Islam. Jiménez de Rada, testigo presencial del combate, explica el episodio de la toma de Calatrava en función de la providencia divina, identifica a Alfonso VIII como un nuevo mártir dispuesto a morir por la fe de Cristo y enfatiza, de forma excepcional, el valor adquirido por la cruz-insignia del ejército cristiano en la batalla. En la misma línea, Tuy identifica a los castellanos como los adorantes crucem y la Crónica Latina atribuye al signo poderes sobrenaturales. Los citados cronistas defienden el concepto de cruzada dado a la Reconquista y en su relato del combate de 1212 coinciden en señalar la cruz como la seña y símbolo del ejército cristiano y, en último término, de su rey. El cenotafio burgalés, por tanto, con el cincelado de la cruz en el sarcófago de Alfonso VIII representa escultóricamente esta idea político-religiosa. Además, la cruz esculpida es marcadamente anicónica secundando la estela del lábaro constantiniano o las cruces visigodas y asturianas, revitalizadas en la literatura contemporánea.

Los sepulcros de Alfonso VIII y Leonor de Plantagenet evocan en sus relieves figurativos los momentos clave de la biografía real, leáse aquéllos que la literatura especular califica de exemplum y modelos a seguir. Lo novedoso del sentido narrativo-cronístico de estas secuencias, como hemos visto, coincide perfectamente con el mensaje transmitido en los textos políticos y literarios contemporáneos sobre la perduración de la buena memoria y la fama de gobernantes y monarcas.

\subsubsection{Imago maiorum regias. Los simulacros de Fernando III y Alfonso X}

La historiografía tradicional ha insistido en la ausencia de imágenes fúnebres en la Castilla medieval. Efigies que, perpetuando la tradición de las imago maiorum romanas, formaban parte del cortejo y, al llegar al lugar de inhumación, centralizaban la fase de la exposición del finado e incluso permanecían en el mismo lugar hasta la colocación de la lápida. Testimonios literarios y la arruinada capilla regia hispalense permiten matizar esta afirmación.

\footnotetext{
52 La apropiación de esta iconografía religiosa en la temática de donación y patronato ha sido resaltada por SÁNCHEZ AMEIJEIRAS, R.: Investigaciones iconográficas sobre la escultura funeraria del siglo XIII en Castilla y León, Universidad de Santiago de Compostela, 1993, Microfichas, pp. 216 y ss.

53 Vid. NieTo Soria, J. M.: "Del rey oculto al rey exhibido: un síntoma de las transformaciones políticas en la Castilla bajomedieval”, en Medievalismo, Madrid, 2 (1992), p. 11.
} 
La farsa de Ávila donde se simbolizó la destitución de Enrique IV mediante el derrocamiento de su estatua es un ejemplo válido pero tardí ${ }^{54}$. En un espectro cronológico más afín, tenemos el episodio del Poema de Fernán González referido a la labra de una estatua del conde: Fagamos nos señor de una piedra dura,/ semejable al buen conde, d'essa mesma fechura:/ a aquella imajen fagamos todos jura... por amor del buen conde por señor le ternemos/ pleito e omenaje todos a ella faremos./ La seña de Castiella en la mano l'pongamos... 55 . Con la ceremonia del besamanos, los castellanos refrendaban la lealtad y fidelidad a su señor que, en estos momentos, permanecía preso. La "semejanza" fisionómica de la efigie y el pendón que portaba en la mano eran los rasgos y atributos individualizadores del héroe castellano evocado y homenajeado en su imago.

En estos términos, hemos de entender la escenografía de la desaparecida capilla hispalense conformada por la disposición gradual descendente de la Virgen de los Reyes, las efigies de Fernando III, Alfonso X y Beatriz de Suabia y los sarcófagos de los respectivos monarcas situados bajo la zona sobreelevada que actuaba a modo de cripta ${ }^{56}$. Las imágenes regias eran esculturas sedentes de tamaño natural. Vestían trajes de aparato -sayas, pellotes y mantos- adornados con emblemas heráldicos, similares a los que exhibe Alfonso en distintas miniaturas de las Cantigas, y portaban atributos de poder convertidos en suntuosas obras de orfebrería. Todo evoca un verismo buscado, aunque es imposible hablar de retratos fideginos ${ }^{57}$.

En el centro, sobresalía Fernando III con corona, espada y vaina. El útil bélico permanecía en la diestra del monarca como rememora la Crónica de Juan II en la cita del gesto del infante don Fernando de tomar e sacar la espada de la mano del rey don Fernando antes de iniciar el combate contra el infiel ${ }^{58}$. Nada dice el texto cronístico sobre un detalle importante: la posición del arma. Sellos medievales de la época y, sobre todo, las viñetas centrales de la Cantiga 292 del códice de Florencia visualizan que el monarca, conforme a la costumbre, no sostenía el estoque en posición de descanso con el filo apoyado en el suelo, sino erguido por la empuñadura ${ }^{59}$ [figura $\mathrm{n}^{\circ}$ 5]. Laguna Paúl ha interpretado el gesto como un símbolo de autoridad regia. Apoyamos esta tesis por su conexión con la iconografía del monarca victorioso o el miles Christi invicto que, asimismo, corroboraban las pinturas de Santa Elena y del rey don Fernando que ganó Seuilla que, situadas en dos pilares fronteros a la capilla de los Reyes, declaraban al monarca como paladín de la cruz y restaurador del cristianismo 60 .

Alfonso X con corona de oro y piedras preciosas sostenía en sus manos el cetro aguiliforme ${ }^{61} \mathrm{y}$ la manzana de oro rematada en cruz. La imago de Alfonso X participaba su consideración como buen

\footnotetext{
54 Según las Crónicas, extramuros de la ciudad de Ávila, se levantó un tablado donde se colocó una silla real -con todo el aparato acostumbrado de poner a los reyes- con una estatua del rey -en la silla una estatua, a la forma del rey don Enrique con corona en la cabeça e çetro real en la mano- a la que, el arzobispo de Toledo quitó la corona; el marqués de Villena, el cetro, el conde de Plasencia, la espada; el maestre de Alcántara y los condes de Benavente y Paredes, los otros ornamentos reales. Con estos gestos se simbolizó la deposición en el cargo de Enrique IV (Crónica Anónima de Enrique IV de Castilla 1454-1474 (Crónica Anónima), ed. crítica y comentada de Mª del P. Sánchez-Parra, Madrid, t. II, 1991, pp. 160-161.

55 Poema de Fernán González, p. 163, ests. 661-662.

56 MartíneZ de Aguirre defiende que Alfonso X encargó las estatuas de sus progenitores, correspondiendo a su hijo Sancho la petición de la imagen del monarca sabio ("La primera escultura...", pp. 118-119).

57 Martínez de AguiRre evoca para este formato modelos imperiales ejecutados en Italia ("La primera escultura...", pp. 120-122). Recientemente, Alonso Alvárez ha planteado una sugerente vinculación con las imágenes funerarias de Carlomagno en Aquisgrán y del Cid en el monasterio de Cardeña ("De Carlomagno al Cid: la memoria de Fernando III en la capilla Real de Sevilla”, en Fernando III y su tiempo (1201-1252). VIII Congreso de Estudios Medievales, León, 2003, pp. 480-482).

58 Crónica de Juan II de Castilla, edición de Juan de Mata Carriazo y Arroquia, Madrid, 1982, p. 191.

$59 \mathrm{Al}$ citado artículo de Aguirre, añadimos los trabajos de SANZ, M J.: "Imagen del tabernáculo de la Capilla Real de Sevi1la a través de dos sellos medievales", en Laboratorio de Arte, Sevilla, 11 (1989), 51-67 y GómEz, E.: "Sello del concejo de Sevi1la", en Metropolis Totivs Hispaniae, p. 286.

60 Cita la existencia de estas pinturas LAGUNA PAúL: "La aljama cristianizada”, pp. 60 y 49.

61 Según MARTíneZ de AguirRe, este símbolo imperial no había sido empleado con anterioridad por ningún rey hispano [“La introducción de la escultura gótica en Sevilla (1248-1300)”, en Metropolis Totivs Hispaniae, p. 125]. El cetro aparece en
} 
Fig. 3. Sarcófagos de Alfonso VIII y su esposa doña Leonor. Detalle (Monumentos Arquitectónicos de España. Burgos, Miraflores, Huelgas, 1880).

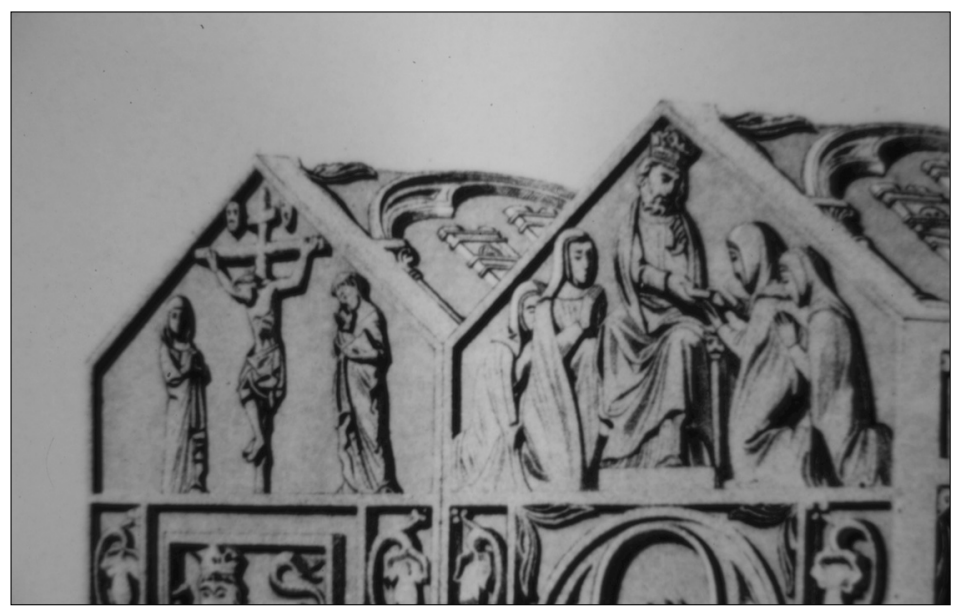

Fig. 4. Sarcófago de Alfonso VIII. Detalle del rey donante.

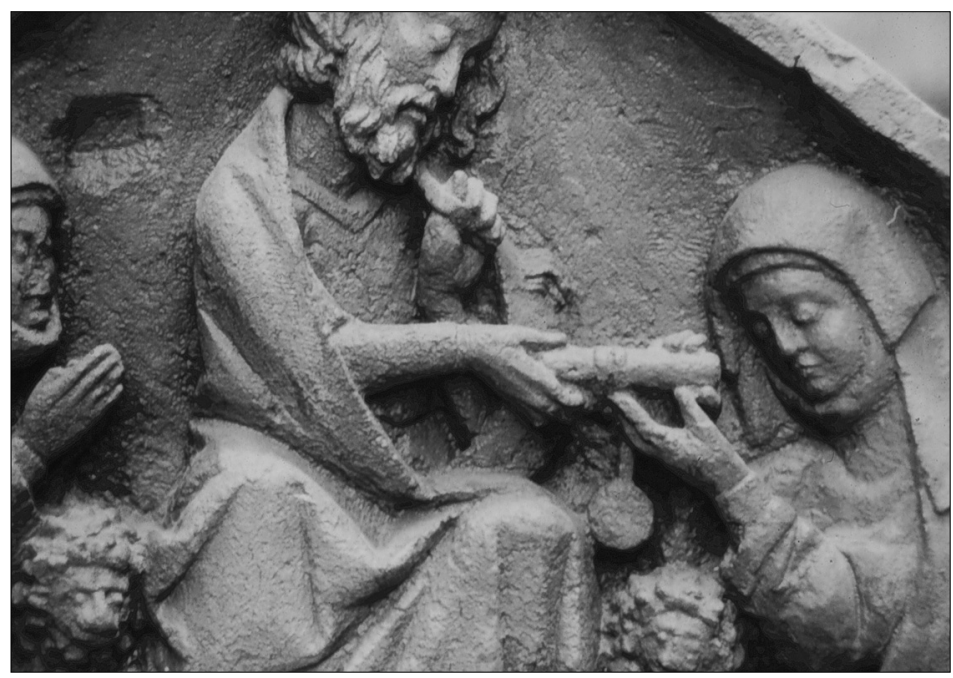

Fig. 5. Imago de Fernando III (Cantigas de Santa María 292d, Biblioteca Nacional de Florencia, MS Banco Rari 20).

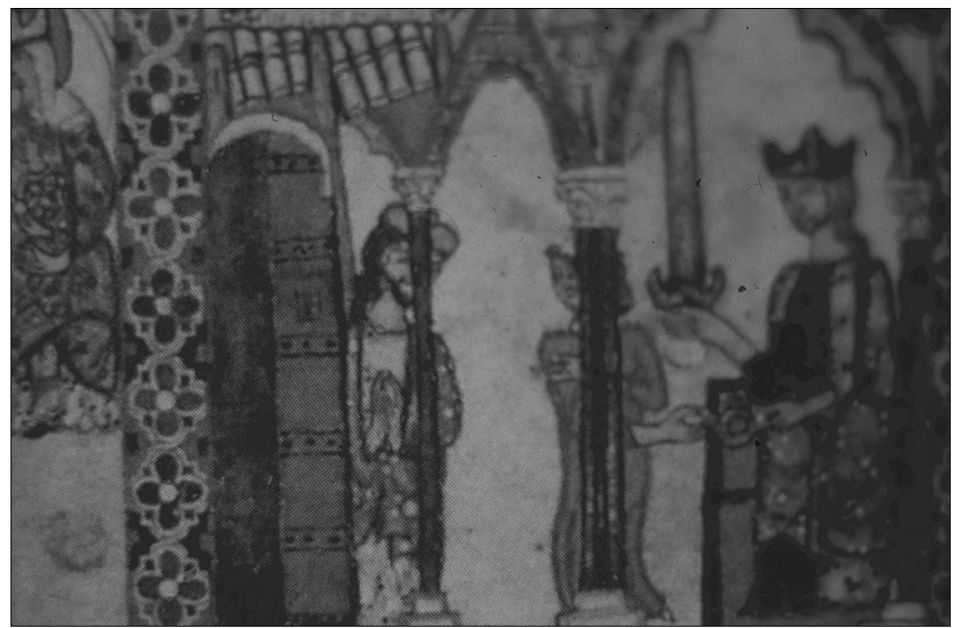

AEA, LXXX, 320, OCTUBRE-DICIEMBRE 2007, 379-394, ISSN: 0004-0428 
gobernante y evocaba la anhelada aspiración política del monarca sabio, el Imperio. El simulacro real no era un unicum en la imaginería alfonsí. Varias viñetas de las Cantigas aderezan la vestimenta real con águilas de alas explayadas [figura $\mathrm{n}^{\circ}$ 6]. La repetición de tales regalías en una miniatura del Ordenamiento de Alcalá , obra de Nicolás González $(1348)^{62}$, prueba la fortuna de este iconograma.

Los simulacros de Fernando III y Alfonso X recibían el mismo protocolo que los reyes. Significativo resulta el gesto del aludido infante don Fernando de acompañar la devolución de la espada a la capilla hispalense con actos de pleitohomenaje, proskynesis incluida, a las imago regias: $E$ después que fueron tirados todos los brocales, tomó la espada e púsola en mano del rey don Fernando. E besóle el pie e la mano, e al rey don Alonso la mano, e a la Reyna la mano. El ademán coincide con el realizado por los castellanos al conde Fernán González y, sobre todo, con el contenido del citado texto de las Partidas sobre la honra debida a la imagen del rey porque es en su remembrança do él non está63. Tal era la función de estas imago: el recuerdo permanente o la buena memoria de las personas que representan, entendida en términos de propaganda y legitimidad dinástica.

Delante de los simulacros, estaban los sarcófagos regios de forma paralelípeda con cubierta en albardilla. El del monarca santo era alabastrino con relieves de castillos y leones e inscripciones que publicitaban en latín, castellano, hebreo y árabe el momento del óbito ${ }^{64}$. Los de la pareja real eran ataúdes de madera recubiertos de piezas troqueladas de plata con motivos heráldicos.

Completaba la escenografía de la capilla la llamada Virgen de los Reyes (c. 1220-1240), talla sedente con el Niño en el brazo ${ }^{65}$. La leyenda que identifica a sus artesanos con ángeles está en la estela de una larga tradición cultual que vincula el labaro constantiniano o la cruz de Alfonso II y que, en último término, individualiza obras artísticas de un notable valor simbólico-representativo. La crítica actual considera la talla un obsequio realizado al rey Fernando por Luis IX de Francia o el emperador Federico II ${ }^{66}$. Interesa resaltar que sólo tiene trabajados en detalle cabezas y manos y conformaban su cabello delgados cordoncillos de oro sujetos por puntas de madera. La estatua, aderezada con ricas vestiduras y una corona regalada por Alfonso X, es una imagen de vestir con las articulaciones móviles y un mecanismo que le permitía girar la cabeza en determinadas ceremonias litúrgicas, similar al dibujo del Álbum de Villard de Honnecourt (1225-1235) relativo al epígrafe como se hace girar la cabeza del águila cuando el diácono lee el evangelio. La movilidad de esta talla, ligada a la tradición de los autómatas del mundo bizantino e islámico, no fue excepcional en la corte alfonsí. Diferentes viñetas de las Cantigas muestran a imágenes marianas que, según la narración, andan, amonestan o cobran vida [figura $\mathrm{n}^{\circ}$ 7]. Juzgamos plausible hacer extensivo el carácter móvil a las figuras regias; de ser así estarían perfectamente configurados todos los ingredientes de este ámbito fúnebre convertido en una suerte de escenario parateatral donde acontecían ceremonias de carácter litúrgico y cortesano contempladas por una nutrida feligresía convenientemente jerarquizada en el espacio catedralicio.

\footnotetext{
otras representaciones artísticas del monarca vid. LÓPEZ GuTIÉRREZ, A.J.: "Sevilla, Alfonso X y el sigillum aureum", en Archivo Hispalense, Sevilla, 220 (1989), 309-320 y NUÑEZ, M.:"Non avemos mayor sobre nos en lo temporal: Alfonso X y la imagen de autoridad, en Temas medievales, 3 (1993), 29-48.

62 "Ordenamiento de Alcalá", en Metropolis Totivs Hispaniae, p. 284.

63 El Speculo expresa la misma idea en similares términos (AlFonso X: Especulo, Libro II, Título XIV, Ley VI, p. 167).

64 Desmontada la capilla a causa de las obras de la nueva catedral, los epitafios se han conservado al reutilizarse como base a la urna de plata realizada posteriormente por Juan Laureano de Pina (LAGUNA PAúL: "La aljama cristianizada", p. 61).

65 La Cantiga 292 de Alfonso X el Sabio cuenta un milagroso suceso vinculado a la Virgen de los Reyes (ca. 1220-1240): la aparición en sueños del rey Fernando al orfebre Pedro de Toledo para que acudiese a Sevilla a colocar en el dedo de la Virgen, como ofrenda, el anillo real.

66 Sellos de la época y las viñetas miniadas de la citada Cantiga 292 certifican que originalmente la Virgen sostenía al Niño con su brazo, correspondiendo a una época incierta su fisonomía Sedes Sapientiae. La talla mariana presidió el altar mayor de la primitiva iglesia mezquita y, posteriormente, la capilla real organizada por Alfonso X. Vid. LAGUNA PAúL: "La capilla de los Reyes", pp. 244-245.
} 
Fig. 6. Imagen de Alfonso X (Cantigas de Santa María 90 c-d, Monasterio San Lorenzo de El Escorial, ms. T.I.1).

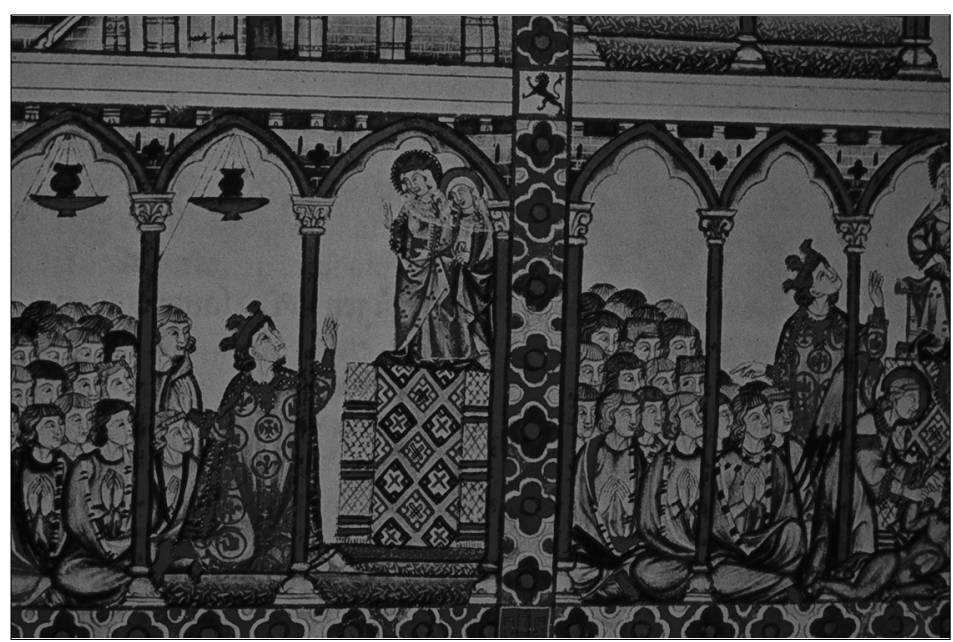

Fig. 7. "Movilidad" de la imagen mariana (Cantigas de Santa María 248 e, Monasterio San Lorenzo de El Escorial, ms. T.I.1).

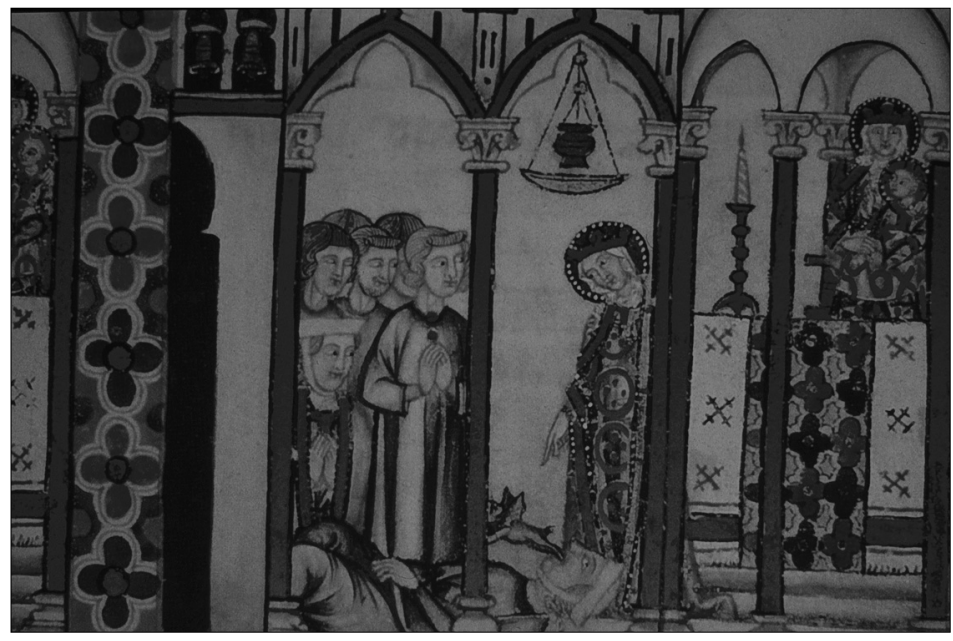

Fig. 8. Sepulcro del infante don Felipe. Detalle de la procesión fúnebre (Villálcazar de Sirga, Palencia).

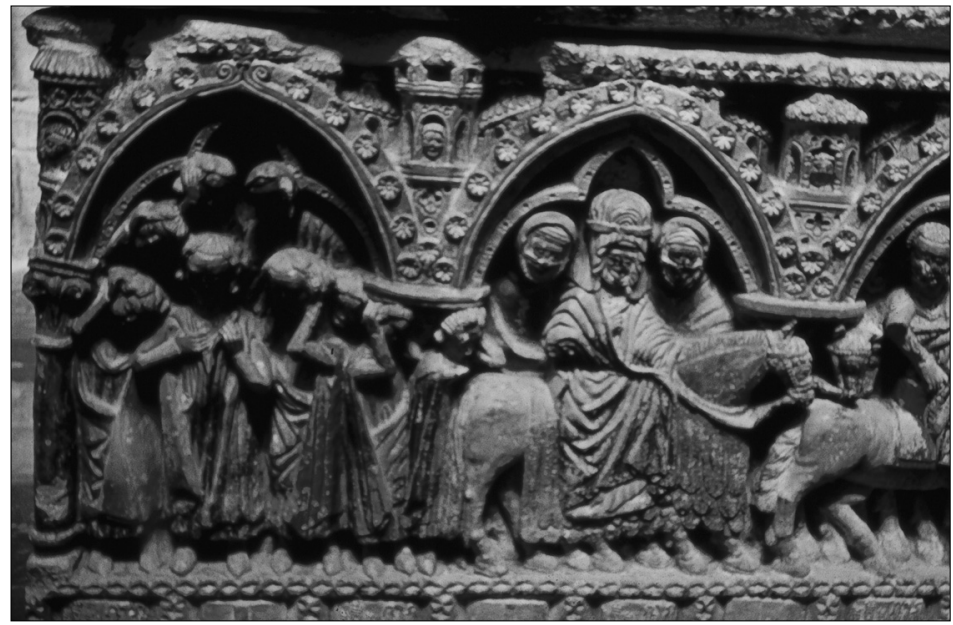


Las esculturas regias estaban cobijadas en sendos baldaquinos. Además, la talla mariana permanecía en un tabernáculo de plata y piedras preciosas con portezuelas móviles blasonadas con castillos y leones; a ellas alude la Cantiga 292 de Alfonso X en la frase portas d'our e non d'outro metal. La movedura de estos batientes desempeña un medido papel visual: cuando se abrían, la imagen religiosa focaliza el espacio funerario; al cerrarse, la Virgen quedaba oculta por una pantalla opaca heráldica que reflectaba su protagonismo a los simulacros regios ${ }^{67}$.

$$
* * *
$$

El largo excursus nos remite al inicio del artículo, es decir, a hablar de dos palabras en principio antagónicas: muerte y fama. La literatura glosó el aparato y ceremonial de las exequias regias que, en ciertos casos, fueron mimétizados por personajes de alcurniar. Lo apreciamos en el túmulo del infante don Felipe de Villalcázar de sirge (Palencia), auténtica réplica pétrea a la política centralista de Alfonso X [figura $\mathrm{n}^{\circ}$ 8]. Su orgullo no disimulado se aprecia en el reiterado recurso a la heráldica que publicita su condición de hijo de Fernando III y en el gesto acechante de su espada. Excepcional en la iconografía de un yacente, resultan innegables las concomitancias de este ademán con el del de Fernando III de la capilla de los Reyes - ¿conocido por el infante en su época de arzobispo de Sevilla?- y con la estatua del monarca santo en la galería de retratos regios del Alcázar de Segovia ${ }^{68}$ donde el simbolismo religioso de las empresas bélicas del conquistador de Sevilla se materializa de forma clara en la cabeza del musulmán colocada a sus pies.

Los sepulcros regios, tal como hemos visto, eluden las referencias sincrónicas y puntuales de los funerales para elegir otras más imperecederas o ejemplares. El cenotafio de Alfonso VIII introduce como novedad un sentido narrativo, similar al empleado en el incipiente relato cronístico, destinado a enfatizar los hechos más significativos del monarca, léase su patronato eclesiástico y la tarea militar ligada a la guerra santa contra el infiel. La evocación del cursus honorum del monarca fallecido en el marco de lo funerario adquirió una gran vigencia en el tiempo; basta recordar que, en época de los Austrias, bocetos con los principales hitos de rey difunto se hicieron expresamente como exorno del templo donde se oficiaban las exequias reales ${ }^{69}$.

En la capilla hispalense de los Reyes, el hecho sincrónico se sitúa en la pintura del rey que ganó Sevilla colocada en el pilar frontero a la entrada del ámbito fúnebre. La majestad regia se centraliza en las imago, entendidas según los textos de la época como sustitutos del monarca fallecido o remembranzas permanentes de los reyes. Los simulacros, igual que las estatuas de Apolonio labradas por los habitantes de Mitelene y Tarso o la escultura de Fernán González cincelada por los castellanos en un momento de reclusión del conde, actuaban como metáforas imperecederas del quehacer gubernativo, tal como glosan los últimos versos de la estatua de Apolonio quanto el sieglo dure, fasta la fin venidas,/será en Mitelene la su fama tenida.

Recibido: 26-V-2005

Aceptado: 17-III-2006

${ }^{67}$ La canonización de Fernando III en 1671 y el encargo de un nuevo retablo provocó la destrucción de estas estructuras de las que subsisten dos placas de plata con león rampante y castillo (siglo XIII) [HERNÁNDEZ NUÑEZ, J.C.: "Placas con león y castillo", en Metropolis Totius Hispaniae, p. 276]. Finalmente, en 1433 y en el contexto de la construcción de la nueva catedral, Juan II autorizó el derribo de la vieja capilla real. Más datos en Marías Franco, F.: "Sobre la cabecera de la catedral de Sevilla", Archivo Español de Arte, 189 (1975), 136-188.

68 Sobre este ámbito desgraciadamente desaparecido vid. COLLAR DE CácERES, F.: "En torno al Libro de retratos de los reyes de Hernando de Ávila", en Boletín del Museo del Prado, Madrid, t. IV, nº 10 (1983), p. 14.

69 Goldenbeerg Stoppato, L: "Los lienzos con historias de la vida de Felipe II 13 de septiembre-12 de noviembre de 1598", en Glorias efímeras. Las exequias florentinas por Felipe II y Margarita de Austria, Valladolid, 2000, 155-158. 